
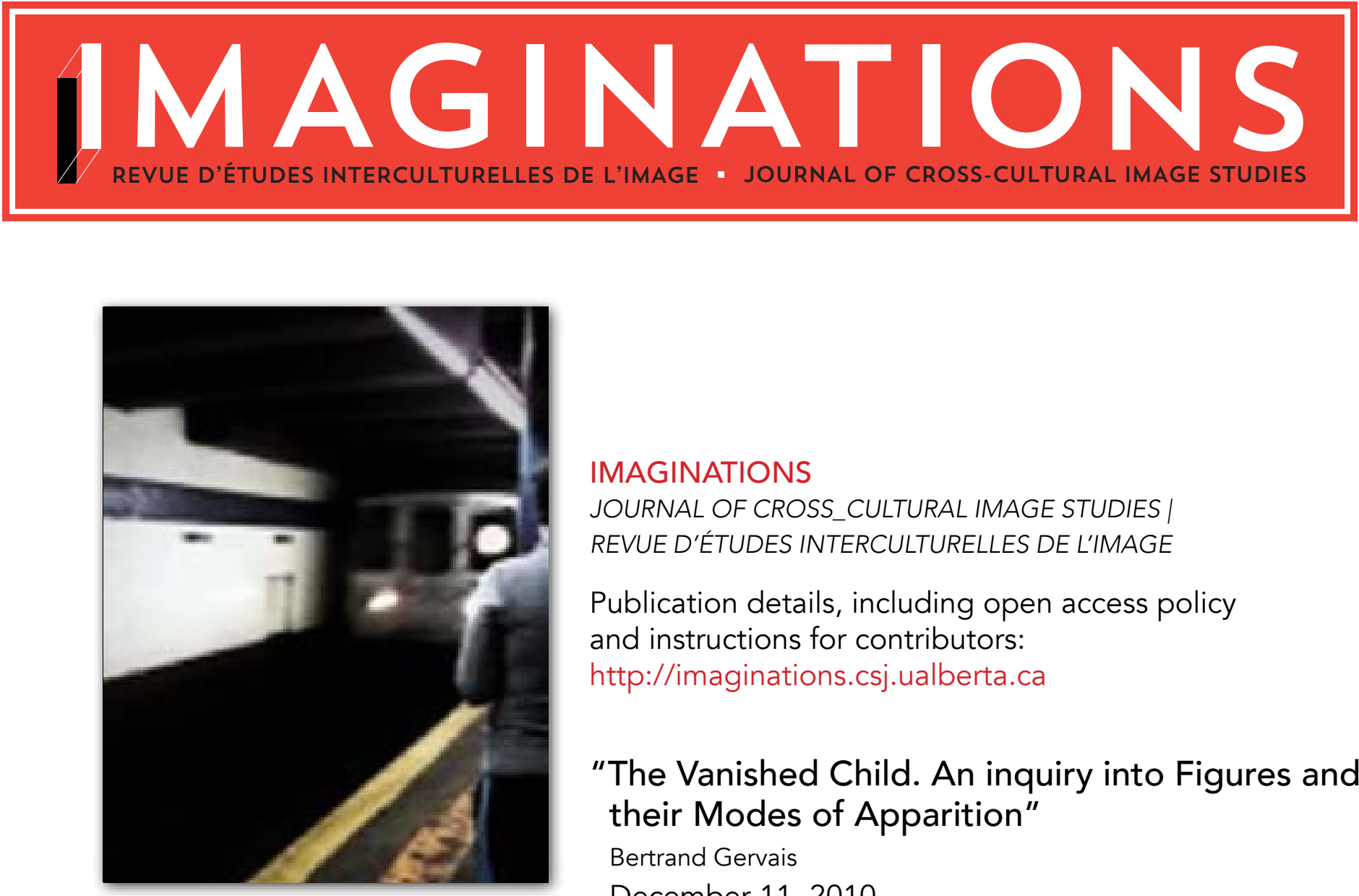

\title{
IMAGINATIONS
}

JOURNAL OF CROSS_CULTURAL IMAGE STUDIES |

REVUE D'ÉTUDES INTERCULTURELLES DE L'IMAGE

Publication details, including open access policy

and instructions for contributors:

http://imaginations.csj.ualberta.ca

\section{"The Vanished Child. An inquiry into Figures and their Modes of Apparition"}

Bertrand Gervais

December 11, 2010

To Cite this Article:

Gervais, Bertand. "The Vanished Child. An inquiry into Figures and their Modes of Apparition" Imaginations 1:1 (2010): Web (date accessed) 72-92. DOI: 10.17742/IMAGE. inaugural.1-1.6

To Link to this article:

http://dx.doi.org/10.17742/IMAGE.inaugural.1-1.6

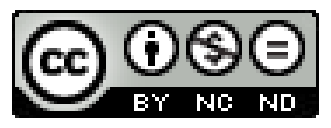

The copyright for each article belongs to the author and has been published in this journal under a Creative Commons Attribution NonCommercial NoDerivatives 3.0 license that allows others to share for non-commercial purposes the work with an acknowledgement of the work's authorship and initial publication in this journal. The content of this article represents the author's original work and any third-party content, either image or text, has been included under the Fair Dealing exception in the Canadian Copyright Act, or the author has provided the required publication permissions. 


\title{
imaginatinne
}

\section{The Vanished Child:}

\section{An inquiry into figures and their modes of appearance}

\author{
Bertrand Gervais [Trans. with gullLaume bauer]
}

WHAT IS A FIGURE? When does it appear? How can we describe the moment of its appearance? By what process does an indistinct noise become a sound? How does a simple thing become a sign, filled with meaning?

A figure often appears in a moment of enticement. At first, there is nothing. Then, suddenly, something pops up and changes everything. It is a revelation, an unprecedented moment in which a presence appears to us, in which a truth imposes itself subtly and dictates its own law. Witold Gombrowicz described this precise moment in his journal. He identifies it in a resolutely sarcastic manner:

$[\mathrm{F}] \mathrm{rom}$ the immensity of phenomena taking place around me. I draw one thing. I notice, for example, the ashtray on my table (the rest of the objects on the table slip into non-being).

If I can justify why I noticed the ashtray in particular ("I want to drop my cigarette ash"), everything is all right.

If I noticed the ashtray accidentally, without any intention, and I never return to this observation, everything is still as it should be.

If, however, having noticed this phenomenon without significance, you return to it for a second time ... woe! Why did you notice it again if it is without significance? Ah, so it means something to you after all, if you returned. ... Oh yes, by dint of the fact that you concentrated unjustifiably on this phenomenon one second longer, this thing already begins to stand 
out, becomes remarkable. ... No, no (you deny), this is an ordinary ashtray! -Ordinary? Why are you denying it if it is ordinary?

This is how a phenomenon becomes an obsession. (161)

We recognize easily Grombrowicz's caustic humor, but the situation he describes delineates the initial moments in the actualizing process of a figure. It appears in this gaze that lingers and, all of a sudden, invests itself in the creation of an object, a semiotic object, whose power comes from this very gaze, which captures and composes it. One second too many, says Gombrowicz, that is all that is needed for an ashtray to be transformed into a sign, this haunting symbol, which is a figure. Further, the obsession, which can emerge from this intuition points to the way in which a figure, if it appears at first sight as a truth for the subject, remains always principally opaque, illegible. The figure is a truth, but one that must be interpreted and whose effects just barely begin to make themselves felt. It attracts and, at the same time, resists appropriation by the subject; it manifests itself as an enigma that is both troubling, in its compelling demand for resolution, and reassuring, in the way that it is already set in place.

The figure is an enigma; it sets the imagination in motion. This object of thought is given a meaning, a function, and even a destiny. Once apprehended, the figure becomes the focal point of an imaginary construction, a construction of the Imaginary. ${ }^{2}$ It does not remain static, but calls for interpretations through which the subject simultaneously takes hold of the figure and loses itself in its contemplation.

Imagination at work

In Don DeLillo's novella, The Body Artist, we find a simple, yet incredibly effective example of the process of figuration. Lauren, the heroine, approaches a town in her car. She catches sight of a man seated on a veranda. He is blond and his face is large:

She felt in that small point in time, a flyspeck quarter second or so, that she saw him complete. His life flew open to her passing glance. A lazy and manipulative man, in real estate, in fairview condos by a mosquito lake. She knew him. She saw into him. He was there, divorced and drink-haunted, emotionally distant from his kids, his sons, two sons, in school blazers, in the barest blink. (70)

Here is a figure in all its spontaneity: an imaginary construction, a thought that unfolds itself out of almost nothing, from a glance given to a silhouette spotted 
between the branches. Lauren fabricates an entire life on the basis of a fleeting look. Despite its frailty, its ephemeral nature, this figure imposes itself on her thoughts, but on ours as well because we easily succeed in imagining this bitter and disillusioned man. However, this figure is based on nothing. It is only a fantasy, a daydream into which a woman ventures during a few instants, while sitting behind the wheel of her car. There is no man on the veranda. As the text subsequently makes clear, when passing in front of the house, Lauren understands that "she was not looking at a seated man but at a paint can placed on a board that was balanced between two chairs. The white and yellow can was his face, the board was his arms and the mind and heart of the man were in the air somewhere [...]" (70). The figure is an imaginary object, a product of the imagination that, even though it is more or less motivated, springs up to crystallize otherwise diverging thoughts.

Lauren's projection, this musement initiated by a fleeting vision, points to the way in which a figure appears, to the subject who approaches and seizes it, as a complex sign having a precise configuration, composed of a set of traits, as well as a singular way of being (setting in motion, for example, its own narrative and iconic logic), involved in both acts of imagination and representation, made for one's self and for others.

Playing an essential role in this essay, the term musement must be clarified. A simple definition describes it as the drifting of thoughts, a kind of mental wandering, a pure game of associations, which begins when we drift into a continuous movement of thought. It is a rush, which runs through us until we free ourselves from it for one reason or another. It is a form of internal discourse, whose function is not that of an occasional drifting, but, truly, that of the motor of our thoughts.

The concept was initially defined by Charles S. Peirce in his article "A Neglected Argument for the Reality of God" (262-63). ${ }^{3}$ Peirce began by describing musement as a kind of daydream, with no loss of consciousness, no complete absence of the self. It is a form of play, of pure play, as he puts it, a play with no rules except the very necessary ones of liberty, of associations, and of the establishment of new ties.

There is a certain agreeable occupation of mind which, from its having no distinctive name, I infer is not as commonly practiced as it deserves to be; for indulged in moderately $[. .$.$] it is refreshing enough more than to repay$ the expenditure. Because it involves no purpose save that of casting aside all serious purpose, I have sometimes been half-inclined to call it reverie, with some qualification; but for a frame of mind so antipodal to vacancy and

Jaurnal of Crass Cultural Image Studies - Revue d'Études Interculturelles de I'Image

Imaginations, I-I, 2010 Copyright @2. Open Journal Systems. ISSN - 1918-8439. 
dreaminess such a designation would be too excruciating a misfit. In fact, it is Pure Play. Now, Play, we all know, is a lively exercise of one's powers. Pure Play has no rules, except this very law of liberty. It bloweth where it listeth. It has no purpose, unless recreation. (262-63)

Musement is imagination at work with all that this faculty possesses by way of the unforeseen. Think of Lauren imagining a man from a simple branch, constructing a narrative out of thin air.

Thomas Sebeok followed Peirce's definition quite closely, putting the emphasis on imagination, taking up Jacob Bronowski's position (Sebeok 3). Michel Balat, the French semiotician, has gone on to present musement as the continuous movement of thinking, a stream that flows through us. We can silence this musement, we can bury it away under the strata of our rationality, keep it at a distance, just like we can try to take hold of it, to make it meaningful during periods of introspection or with the help of various processes. But, we cannot stop it. It is at the root of our cognitive and mental activity. Balat compares its process to free association, practiced in psychoanalysis, which is not musement per se but rather a way to imitate its play. This comparison, however, accentuates not so much the great freedom of this form of association, but its uncontrollable, unintentional nature. There is something impetuous in musement, and what we recuperate is only the smallest share of it, a fixed, stopped musement, like water in a glass taken from a river. As Balat writes, it takes:

[T] he form of that kind of thought to which we only have access when an impromptu, discordant event reveals it to us. "Well, I was thinking...," a sentence we could read as "I was in the middle of a thought" (or of a thinking process). This first kind of musement is not directly accessible to us since, while we were musing, we had no consciousness of this. Musement presents itself to us as pure hypothesis, pure possibility, a walk in the original Universe, the indefinitely present moment irreparably destroyed by actuality or actualisation which provides a past tense. In its highest activity, musement constructs, builds up this kind of idea which may or may not pass the barrier of expression without completely fading away but to which the evidence of its presence reality testifies. ${ }^{4}$

Musement is that which goes on in the background while our attention wanders. It gives access to the shadowy area of thought, which can only be seized by sudden movements, by plunges into the pure play of possibility. Because it is of the order of the unspeakable, of that which breaks away, musement does not give itself headlong to us in all the transparency of a frank and direct glance, but rather it

Jaurnal of Crass Cultural Image Studies - Revue d'Études Interculturelles de I'Image

Imaginations, I-I, 2010 Copyright @2. Open Journal Systems. ISSN - 1918-8439. 
offers itself up to be constructed or reconstructed by way of complex inferences. Continuing the comparison with psychoanalysis, Balat adds that:

Just as latent thoughts are inferred (by an inference Peirce calls "abductive") from the manifest content of a dream, so musement-insofar as it is not part of the consciousness's domain-must be inferred from the ideas which, because they impose themselves in actuality, censure access to it while opening it up to us. From this moment on, the content of musement will be dependant on that which denies it, at least where access to consciousness is concerned. ${ }^{5}$

Musement can only be grasped through approximations: that which we manage to catch is given up in a necessarily fragmented and raw manner, for it is the motor behind our thoughts, the very process by which they coalesce and stay dynamic. We gain access to some of its results only by chance, an impromptu accident, a brusque movement.

What triggers it is also at stake. If we come out of it abruptly, it seems that we just simply slip into it, unknowingly or inadvertently. One way, as Lauren's example shows, is to be suddenly engrossed by a figure, even one as flimsy as an imagined man on a veranda. Fascinated by a figure, our mind wanders easily and we immerse ourselves in a world of thoughts and associations, of desires and longings, building a narrative as we go along, inventing, as Lauren does, a complete destiny. The story she invents is fragile, it blows away as rapidly as it is conceived; but, in its brief lifespan, a figure coalesces and imposes itself to her consciousness as a complex sign, charged with meaning.

Figure and musement are intrinsically linked. To lose our self in the contemplation of a figure is an apt representation of musement. The appearance of a figure can trigger it, and it can also fuel it. In its weakest amplitude, this musement might resemble a simple distraction, a roaming similar to that which takes hold of Lauren in her contact with the paint can. In its strongest amplitude, it leads to dispossession. In Thomas Mann's Death in Venice, for instance, Gustav von Ashenbach becomes mortally obsessed by the figure of the ephebe embodied by the young Tadzio. In Vladimir Nabokov's Lolita, Humbert Humbert follows a similar path in his obsession for the figure of the nymphet Lolita. ${ }^{6}$ Both characters are destroyed by their fascination for figures who all at once enchant them and lead them to their own demise.

The Vanished Child

Jaurnal of Crass Cultural Image Studies - Revue d'Études Interculturelles de I'Image

Imaginations, I-I, 2010 Copyright @2. Open Journal Systems. ISSN - 1918-8439. 
The examples taken from Grombrowicz and DeLillo allow for the identification of two moments in the actualization of a figure, those of its perception and its imagination. Indeed, there can only be a figure if the subject identifies an object in the world, believing it to be filled with meaning. The figure only manifests itself in this revelation of meaning to come. In the same way, it only reveals itself if the subject endows this sign with traits and a narration with which he or she can identify and is able to generate for him or herself. The figure is the outcome of a semiotic production, a production of the Imaginary.

To identify the third moment in the actualization of a figure, I will to give a third example that is the figure of the Vanished Child, discovered while reading Sophie Calle's Disparitions (or, in English, Disappearances). This example will enable me to show that a figure, in order to emerge, requires not only to be perceived and imagined, but, moreover, to be manipulated, the third moment. To imagine a figure is, indeed, to manipulate a form.

What does it mean to manipulate a form? It implies a vast array of processes, among which are: to identify and name it; to play with its image, to develop it; to seek its origin; to use it in various situations, real or imaginary; to muse over it; to muse, therefore, to lose oneself in its contemplation; then, to regain some form of control, trying to tell its story and to explain the fascination it induces; and ultimately, to represent it. The figure is a dynamic sign, which has multiple functions: it serves as a focal point, drawing attention, but it is also used as an interface and a relay, a way of understanding as well as an interpretive principle. It will become clear as I describe the singular situation at the core of Sophie Calle's Disparitions.

In Hebdomeros, an extended prose piece published in 1964, the painter Giorgio de Chirico suggests the following exercise: "When you have found a sign, turn it backwards and forwards on all sides; look at it full face and in profile, threequarter face and foreshortened; make it disappear and notice what shape is assumed in its place by the memory of its appearance" (51-2). The figure is a specific form, which substitutes itself for the vanished object, but whose shape remains ever present in memory. Moreover, in Roman times, the words "figure" and "form" were synonyms so that referring to one was practically the same as referring to the other. ${ }^{7}$

The figure is a form, but one that is based on an initial absence. In fact, like all signs, it takes the place of an object, designated as its referent, of which it reveals its absence while simultaneously giving the illusion of its presence. Yet, this

Jaurnal of Crass Cultural Image Studies - Revue d'Études Interculturelles de I'Image

Imaginations, I-I, 2010 Copyright @2. Open Journal Systems. ISSN - I9I8-8439. 
presence is entirely symbolic and, as a result, paradoxical. It is a presence-absence. The absent is not there, yet never ceases being there, by way of its figure, and it gives rise to speech acts and thoughts. As Roland Barthes writes when describing the act of speaking or of imagining another: "Endlessly I sustain the discourse of the beloved's absence," adding, "the other is absent as referent, present as allocutory" (15).

Absence is at the very heart of semiotic processes. Signs and figures exist only because objects in the world are set at a distance. Every transformation of an object into a sign, from a speech act to a simple musing, is the manipulation of this enduring absence, a game involving figures, which expresses nothing other than the fragility of their own construction. For Barthes, absence, as soon as it implies duration, necessitates manipulation. He writes that it is essential to "transform the distortion of time into oscillation, produce rhythm, make an entrance onto the stage of language. [...] Absence becomes an active practice, a business (which keeps me from doing anything else); there is a creation of a fiction which has many roles (doubts, reproaches, desires, melancholies)" (16). As a dynamic sign, the figure is the result of a manipulation, which succeeds in making the absent present, thus sustaining this precarious presence of another, who is never completely there.

The figure is an object of thought, an idea actualized in a specific context, and, as it is with all such objects, its reality is evanescent and fragile. Yet, it is on this basis that our thinking unfolds, that our acts of reading become something other than the simple progression through texts, but rather explorations into imaginary worlds.

This relationship with absence is illustrated in an extraordinary way through one of Sophie Calle's texts. In Disparitions, the artist introduces a peculiar situation. At the Isabella Stewart Gardner Museum in Boston, a collection of paintings has been stolen, including those by Rembrandt, Manet, Vermeer, Degas, and others. In her will, Mrs. Gardner had insisted that nothing would be touched after her death. "Following the robbery," Sophie Calle writes, "the spaces left by the paintings and the objects were left empty" (11). "Taking advantage of this unusual installation, the artist asked the staff working at the museum, including curators, attendants, and other employees, to describe the stolen objects to her. The paintings, thus, became the pretext to a figural process in which the staff was actively involved. This situation enabled the appearance, if not the apparition as if it was a phantom, of the intriguing figure of the Vanished Child. ${ }^{\prime}$

Jaurnal of Crass Cultural Image Studies - Revue d'Études Interculturelles de I'Image

Imaginations, I-I, 2010 Copyright @2. Open Journal Systems. ISSN - 1918-8439. 


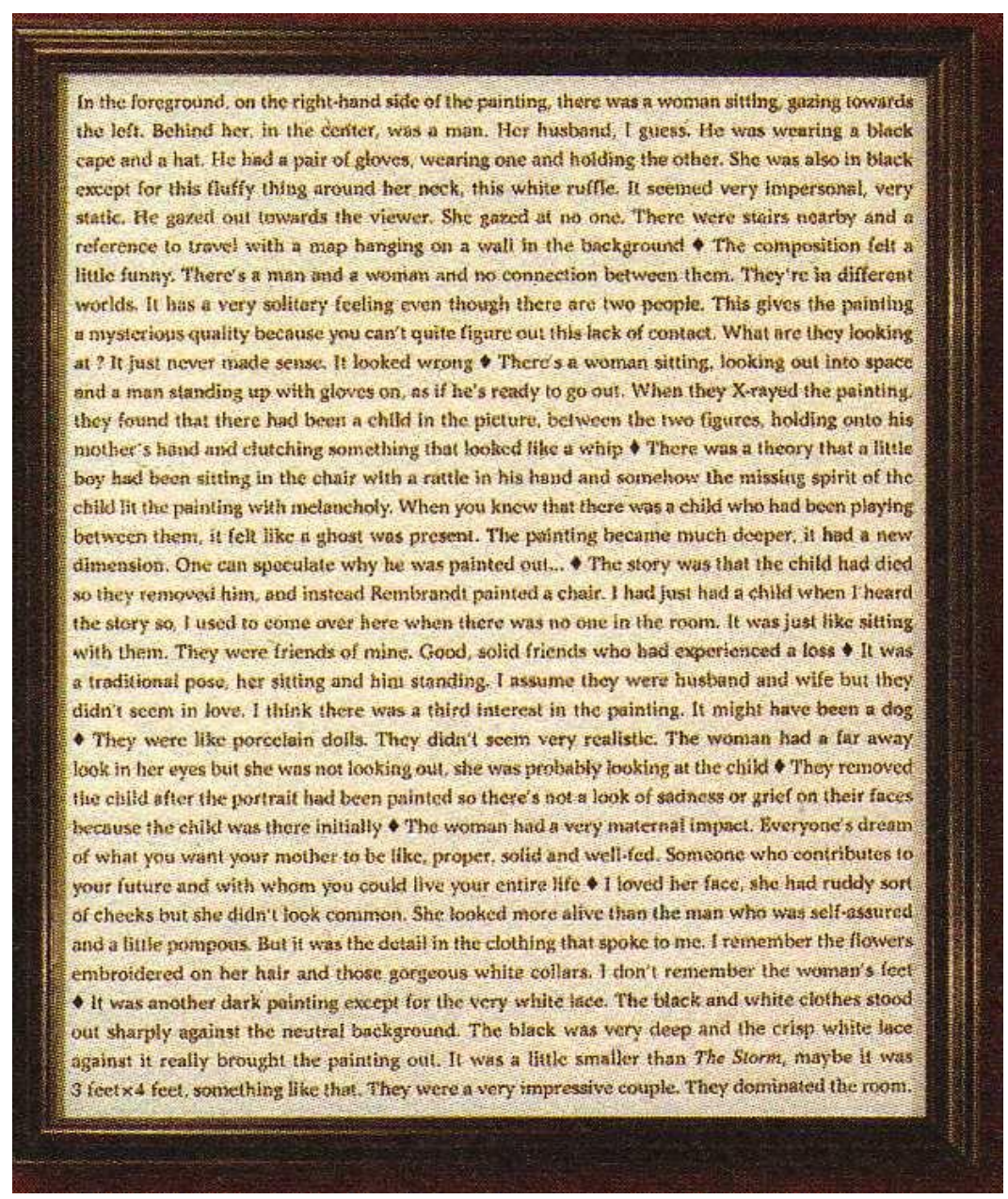

It is important to mention that Sophie Calle's art consists in bringing into the limelight the presence of figures. Daily mundane objects, including address books, beds, telephones, photographs taken during vacations or birthdays, automatic teller machines, posted letters, and dresses, all serve as a pretext in her artwork for the production of narratives, where figures play a key note. In only a few words, her prose, which often serves as caption for her photos and installations, succeeds in capturing the essence of a situation and exploiting its symbolic and affective dimensions. She knows how to bring to light the unexpected in the familiar, exposing the detail in a situation, which transfigures it into something truly theatrical. She makes a novel out of nothing. And out of this singular convergence of elements, through small narratives and unexpected stories, she constructs texts where images play an important role. 
Herve Guibert, the French writer, once said that Sophie Calle was a kind of mischief-maker. In French, the expression used, "faire des histoires," means not so much to tell stories but to complicate things. A "faiseuse d'histoire," in this sense, plays both on Calle's capacity to make a situation confusing and to tell a good story, turning the next to nothing into an event. Much like the literary minimalists (Raymond Carver, Donald Barthelme), Sophie Calle does not write extensive narratives, but stays close to the core of her stories. She takes hold of a given material, be it biography or anecdote, and transforms it into a short fiction, never more than a few pages long. These narratives are like entries in a blog. However, this undertaking is carried out by the creation of figures. This is the case for one of her texts included in Disparitions that brings to light the figure of a vanished or deleted child. Like a figure in the carpet, this child haunts a stolen work of Rembrandt, a portrait painted in 1633, entitled "Portrait of a Couple."

The strategy used in Disparitions has an essentially intermedial quality. The Rembrandt chapter is composed of a photograph, depicting a space that has been left vacant as a result of the robbery of the painting (a wall covered over by drapes in front of which three chairs have been placed). There is a reproduction of a frame in which the twelve accounts have been transcribed with a label identifying the painting and indicating the date of the robbery (March 18 $\left.{ }^{\text {th }}, 1990\right)$. In addition, a French translation of the twelve collected accounts has been included, and each one of these texts has been placed end-to-end, separated by a very discreet lozenge.

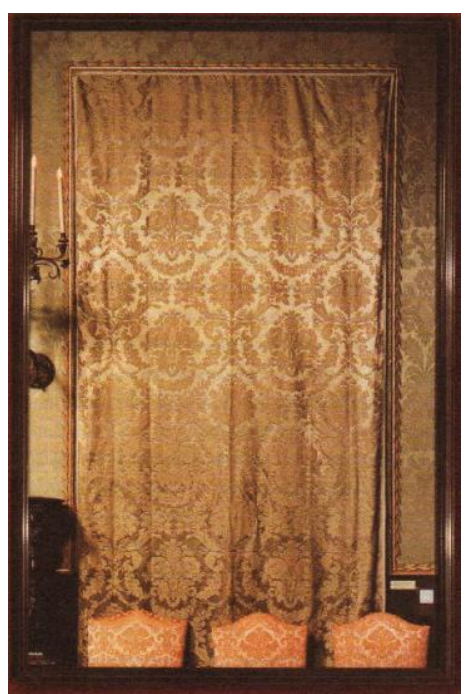

The first two accounts concerning the portrait converge in their expression of the uncanny. For the first witness, the man and the woman painted by Rembrandt appear distant. The man is said to be looking towards the viewer, whereas the 
woman seems to be looking at no one. Everything seems impersonal and static. As the second witness puts it, they are in different worlds: "One feels," s/he said, "a tremendous impression of solitude, in spite of there being two people. This impression gives the painting a mysterious quality because you cannot really understand this lack of contact. What are they looking at?" (24).

The absence of the painting gives rise to words, in the form of a witness account that little by little reconstructs a form, a figure, that of a portrait subtly gone amiss in which separation and a subdued sorrow avail over the feeling of love. The portrait bares the hollowed out traces of a tragedy that divides the couple. We have no difficulty piecing together the scene, even if our only access to it is through brief accounts; and we might be familiar enough with Rembrandt to imagine the stern black clothing of the two spouses, the somber character of their portrait, and the chill evoked by the absence of any relationship between them.

We learn quickly that the painting has been modified. Something has been hidden beneath the surface of the stolen painting. Indeed, the third witness explains the following: "When they examined the painting under $\mathrm{x}$ ray, they found a child between the two characters, holding the mother's hand and tightly holding what resembled to be a whip" (24). Thus, the strangeness of the painting derives from a modification that had been brought to it, a figure that had been removed. This figure was that of a child, covered up perhaps following his death.

This presence of a blotted out child is echoed in the next accounts: "When you knew that there was a child," the fourth witness said, "playing between them, we had the impression that a phantom was present. The painting became more profound. It took on another dimension" (24). As for the eighth witness, s/he asserted that they "had taken away the little boy after the painting had already been completed, in such a way that their faces appear neither sad nor troubled, since the child was originally there" (24).

The accounts are not in agreement with each other concerning the attitude of the couple. Certain of the witnesses see them as two people torn apart from each other, a couple who has already undergone separation in spite of the painting that brings them together. Yet, other witnesses describe them as attentive parents: the woman appears "very maternal," "lively," "respectable, strong, and well-nourished. Someone who cares about your future and with whom you would be able to spend an entire life" (25). The witnesses' opinions differ in accordance. On the one hand, with their knowledge of the disappearance of the child, and on the other hand, with their basic patterns of identification, as their insecurities and doubts are projected onto the depicted characters.

Jaurnal of Crass Cultural Image Studies - Revue d'Études Interculturelles de I'Image

Imaginations, I-I, 2010 Copyright @2. Open Journal Systems. ISSN - 1918-8439. 
Our reconstruction of the painting is a patchwork of partial accounts. We must imagine a vanished child in a painting that has itself disappeared, and we can only do it taking into account the manner in which the witnesses represent the painting for themselves, for their testimonies are based on their own knowledge of the painting's history, their own subjective and esthetic perceptions, and their unique process of identification.

Moreover, there is not only one painting, but two. The first one is the painting of the family with the child. The second one represents a strangely distant couple. The discrepancy between the two paintings results evidently from the disappearance of the child, which goes to show that an absence easily becomes a sign. As a matter of fact, there is a third painting, the one that appears through the witnesses accounts, that of the Vanished Child. This painting is one in which the distance between the couple hides a tragedy that the palimpsest reveals by means of erasure. For the painting itself, the disappearance of the child becomes a source of imbalance in its volumes, a subtle perversion, from which it suffers the aftereffects. Adding to the presence of this third painting, we can even identify a fourth one: the stolen painting whose whereabouts and destiny are unknown. Did the thieves know about the Vanished Child? Was the painting damaged or destroyed?

As readers, we can re-imagine the painting, projecting on to the canvas of our mind a family's tragic destiny, and we can even envision the painting's peculiar fate. The tragedy of the painting is embodied in the fact that nothing remains of it in the museum other than the vacant space left in the wake of its disappearance. The painting and the child have ended up sharing a mutual state of absence. Their destinies have become entangled as the result of a surprising contamination. Of all the paintings that were to be robbed, one bore the marks of a disappearance under its varnished surface.

The child is imbedded in a multilayered disappearance: disappearance of the life of his parents, disappearance of a portrait, and disappearance of the painting itself. However, despite all the layers of absence, an embedding that goes deeper and deeper, the child imposes itself as a figure. Surprisingly, the disappearance of the painting ends up bringing to the surface the disappearance of the child. The robbery gives rise to an act of reminiscence, which dwells upon the tragedy at the very heart of the disfigured scene.

As it were, Sophie Calle's intervention undoes that of Rembrandt. By textualizing the witnesses' accounts, she ends up bringing to the surface what the painter had succeeded in covering up. What the image had kept hidden, the words reveal, in its

Jaurnal of Crass Cultural Image Studies - Revue d'Études Interculturelles de I'Image

Imaginations, I-I, 2010 Copyright @2. Open Journal Systems. ISSN - I9I8-8439. 
very complexity, for, undoubtedly, the figure of the Vanished Child is a semiotic entity of a surprising intricacy. The figure organizes itself around a vacant center, a child that can no longer be seen by anyone, a child who the parents themselves no longer wanted to see. It is also characterized by its singular way of being as well as its own narrative and iconic logic.

This manner of being is ghostliness. The child is a revenant who does not want to be forgotten. Therefore, the painting is haunted by a phantom that now, because the painting itself has disappeared, is the only one left present. The figure of the Vanished Child is, therefore, not just the result of an appearance, but of an apparition, with its overtones of the uncanny and the supernatural. This ghostly or spectral dimension heightens the symbolic aspect present in the process by which an object is transformed into a figure, giving it a spiritual dimension. The figure becomes more than a sign, but becomes a presence, a real presence, which accentuates its experiential nature.

The fourth witness said that, "the spirit of the disappeared child illuminated the painting with a melancholy tone" (24). And, now, this spirit endures alone as the sign of a tragedy at the very heart of this representation. We do not see the Vanished Child, but he sees us. Hidden under a coat of paint, a veil concealing him, he observes us. He attracts our attention with his singular presence. Sophie Calle's text leads us to manipulate the child's absence and opens up a scene that requires all our attention. And, in the end, this scene is so powerful that we are left seeing nothing else than the revenant. The portrait becomes overshadowed by this image of the Vanished Child whose power comes precisely from its invisibility. We easily fill in the gap left by its absence. The vacant wall of the museum becomes a blank text, which we hasten to fill from the very instant our eyes are set on it.

Here is a tragedy left to be imagined, a tragedy whose repercussions we can feel, despite our remoteness from the initial scene. This tragedy is at the core of an act of narration, which gives all its force to the figure of the Vanished Child. However, this force does not stem from the tragedy of the parents or the tragic fate of the child, but from the destiny of the painting, its unusual story. The figure is dense with a series of enigmas, each giving rise to a potential story, and opening the door to an active musement. Why did the parents ask for the figure of their child to be blotted out from the painting? What tragedy brews under this draconian decision? In what manner did Rembrandt carry this out? What kind of fate has his painting encountered throughout the centuries? Who was this Isabella Stewart Gardner, whose collection is at the origins of the museum? Did she have any knowledge of the existence of this Vanished Child? How was the robbery committed? Where is the actual location of the painting today? How was the 
decision taken to leave vacant the walls on which the paintings were originally hung? Why was Mrs. Gardner's will taken so literally? Why did the curators decide to follow her request to leave everything as it was after the robbery? How did Sophie Calle learn about this particular situation, choosing, finally, to inscribe it at the heart of Disparitions? Musing on these questions, one cannot help wonder how labyrinthine destiny can be!

The figure of the Vanished Child comprises all these questions, all these stories left to be told. This revenant does not only haunt a painting. It marks its destiny. It is as if Sophie Calle's artistic project had already been anticipated, serving as the only way to erase the child's absence from the surface of the painting. It was necessary for the painting to disappear in order for the vanished figure, through the witness accounts, to reappear and impose itself as its essential figure. This paradoxical movement resembles that which is described by Benjamin as an experience of déjà vu:

The phenomenon of déjà $v u$ has often been described. Is the term really apt? Shouldn't we rather speak of events which affect us like an echo-one awakened by a sound that seems to have issued from somewhere in the darkness of past life? [...] It is a word, a rustling or knocking, that is endowed with the power to call us unexpectedly into the cool sepulcher of the past, from whose vault the present seems to resound only as an echo. (Berlin 129)

This is a word, a rustling, writes Benjamin, but it is also a figure, which out of the blue appears suddenly to compel our attention. The figure at the heart of this déjà $\mathrm{vu}$ is subjected to double distance, being both near and far away; it is near, yet continually shying away, but also far, while reappearing with the force of something that has been repressed.

What does the figure of the Vanished Child have to say? Evidently, it speaks of us, since it is nothing other than what we have invested in it, without ever even thinking about it. The production of this figure exposes our own fears and desires. As a form, it supports these emotions, enabling their expression. We must all have in our proximity a vanished child that never ceases haunting us, giving rise to memories and narratives. This child says nothing, yet he never stops challenging us, taking a pervasive hold on our imagination through his very absence. 
Imaginations / Gervais 85

\section{Rethreading a figure}

What type of interpretations has Rembrandt's painting been submitted to? What is the impact of Sophie Calle's text on our understanding of the painting? The different accounts offered by the witnesses can only give us a subjective portrait of the painting's content. And we can ask ourselves: where exactly was the child before being blotted out?

The clash between the painting, as it can still be found in catalogues, and its representation in Calle's text brings to light certain unexpected problems, which confirm the interpretive aspect inherent to any description. If the witnesses' descriptions of the parents positioning in the painting generally respect its composition - the man described as standing in place, the woman as sitting, the two appearing distant, as if they were worlds apart-they prove to be much more tenuous where the child's place in the painting is concerned. The third witness indicates that the child held "the hand of the mother and strongly clutched what resembled to be a whip" (24). If it is impossible to comment on the whip (other than the fact that this detail of the description is in disagreement with the fourth witness account in which the object in the boy's hand is described as being a rattle), the actual location of the chair in the painting tells us that this child could not be holding the hand of his mother. The space separating the couple is insufficient for the child to be able to squeeze between them, and the mother's hand lies propped upon the armrest of her chair.

Furthermore, according to the fourth account, the child was seated on a chair. Yet, the only chair in the portrait is positioned at a distance away from the mother. The child, therefore, could not at the same time be seated and be playing between his parents. According to the fifth witness, in fact, the chair had been painted in his place. Reading the accounts, it becomes impossible to decide where the child was. Was he standing, or seated in a chair? Was this chair present in the painting from the beginning, or painted in later to cover up the child's erasure? In examining the painting, it is tempting to conclude that the chair has been added after the fact. Rembrandt must have replaced one volume (the child) by another (the chair) in order to avoid totally offsetting the portrait's composition.

Indeed, despite the precisions given by the third and fourth accounts, which do not, in any way, contradict those given by the other witnesses, the child was not "between his parents," that is, in the space separating them. Actually, the three of them constituted a triangle, and the child was situated at its upper apex. In the painting, each one of the figures occupies a distinct space. Though slightly shifted to the left, the father is farther back and to the center. ${ }^{10}$ The mother occupies the

Jaurnal of Crass Cultural Image Studies - Revue d'Études Interculturelles de I'Image

Imaginations, I-I, 2 ZII Copyright @2. Open Journal Systems. ISSN - I9I8-8439. 
right corner, situated halfway between the two figures. She serves as a necessary intermediary between them. The child is in the foreground, in the left corner. If the man seems open to the world-his gaze affirming this interpretation, while the globe to his right confirms it-, as for the mother, she directs all her attention to the child. In addition, her maternal gaze and her motherly face make this portrait, otherwise quite austere, a friendly family scene.

However, the disappearance of the child turns this perspective on its head, making the painting appear enigmatic. What did the woman look at? The witnesses cannot give a precise answer: "She did not look at anyone," she "looks into the void," " $[t]$ he woman had a remote gaze, but she did not look outside of the painting. She was probably looking at the child" (24-5). The focus of her gaze is open to all kinds of variations. Because the child has been blotted out, the mother no longer looks at anything. She contemplates the void, and her gaze loses itself in the space that has literally been deconstructed. She is midway between anticipation and oblivion. Her progeny has become an absence that her gaze indentifies by its awkwardness. Something attracted her attention, which will never be brought back. She seems to lose herself in the contemplation of a figure that she alone is still able to discern. Yet, this object is no longer present in her world. It has become a pure object of thought upon which she muses. The enigmatic dimension of her gaze is explicable through the musement in which the disappearance of the child has caused her to become immersed.

Where was the child before being blotted out? The portrait shows that he did not occupy the space between the parents, but rather, a privileged position at an apex. His disappearance opened the family triangle on a void. In his place, there remains only an empty chair. Did the child look upon his mother or, as it is with his father, did the world open at his feet? Was he dressed in black, like his parents, or did he wear the same color as the chair cushions of which the red could be a veiled reference to his erasure? The chair, in any case, marks the absence of the child, for it is literally turned toward the mother and empty, an emptiness that opens the mind to the mysteries of absence. Further, if the mother does not look at the chair, the chair, on the other hand, looks at her. It confronts her. It is a sign that only truly holds meaning for her, a sign that is motivated by this filial relation that has been erased.

The unoccupied chair from Rembrandt's portrait is a discreet appeal to the imagination and to the act of refiguring. It is left to us to transform this void into a sign of absence, to sit a child there and to imagine a figure, which could return the mother's admiring gaze.

Journal of Crass Cultural Image Studies - Revue d'Études Interculturelles de l'Image Imaginations, I-I, 2010 Copyright @2. Open Journal Systems. ISSN - 1918-8439. 
Imaginations / Gervais 87

\section{The Auratic Child}

A figure is the result of an act of appropriation. It requires being perceived, imagined, and manipulated. Further, it requires being designated. Every figure has a name, without which the process of figuration remains uncertain. Thus, the figure of the Vanished Child is neither in the painting of Rembrandt nor in Sophie Calle's text, even though it draws its origins from both these works. It appears through an act of reading. Above all, not only is this figure a sign, an object of thought, it also serves as an interface, a dynamic interpreter, giving rise to interpretation. Further, it talks to us about distance and desire.

As soon as the Vanished Child reveals himself, his apprehension is the confirmation of a double distance. He only appears present in the moment in which his absence reveals itself. Present and absent all at once, present because absent, the Vanished Child inscribes himself in a paradoxical space as an entity having an astonishing temporal density, which culminates over time and distance. He becomes the embodiment of a past that looks upon us in the present. This figure exposes a version of the past of which we know nothing, yet, much like an enigma, becomes the source of an endless musement. In the words of Paul Ricoeur this distention of the mind (a distention of "our" mind) is divided up between a disappearance, its enigma, and resolution (34). It gives to the figure a surprising force, which is that of the Imaginary. As long as it holds within itself an element of mystery, it is a pure potentiality. Its indetermination opens the way to the forms of appropriation. This logic has no limit, and above all, it surpasses the spectator's gaze. "Under our eyes, outside of our gaze," Georges Didi-Huberman writes, "something here talks to us about a haunting presence, as if it came back from far away, something which both concerns and escapes us" (102). ${ }^{11}$ The words of Huberman perfectly describe the figure of the Vanished Child. Behind the veil of its own erasure, this figure escapes our complete appropriation, while simultaneously, penetrating us with his gaze. ${ }^{12}$

As a figure, the Vanished Child corresponds to what Didi-Huberman calls, using Walter Benjamin's terminology, an "auratic object." Such an object is "close and distant at the same time, but distant in its very proximity" (102). From the subject who gazes upon it, the figure requires, "a kind of incessant sweep or back and forth movement, a heuristic process in which distances - contradictory distancesare experienced dialectically" (102). The Vanished Child respects this double distance perfectly. He remains both close and distant at the same time. His appearance in Sophie Calle's Disparitions and the illusion of his presence render him almost palpable. Yet, on the other hand, this same presence remains evanescent because any direct trace of him has been eliminated (the painting

Jaurnal of Crass Cultural Image Studies - Revue d'Études Interculturelles de I'Image

Imaginations, I-I, 2010 Copyright @2. Open Journal Systems. ISSN - 1918-8439. 
having been stolen). His figure is only a phantasm, whose reality cannot be confirmed.

In the writings of Benjamin, the notions of trace and aura are intimately linked. They are two different aspects of a same phenomenon. Benjamin thus affirms the following: "The trace is appearance of a nearness, however far removed the thing that left it behind may be. The aura is appearance of a distance, however close the thing that calls it forth. In the trace, we gain possession of the thing; in the aura, it takes possession of us" (Arcades 447). This tension between appearance and disappearance, between possession and dispossession, is at the heart of every figure and the process of enticement to which the subject is exposed, giving rise to musement. Through its traces, its singular manner of existing in the world, the figure gives itself to the spectator, yet in doing so, it exposes the subject to a process of seduction and subjugation, which is the expression of its aura. This aura is actually the very inscription of a figure's desirability. The figure attracts and draws attention unto its self, while continually avoiding being fully grasped. The Vanished Child is exemplary of this way in which a figure appears, stimulating a desire to be seen, but disappearing at the very moment its longing becomes insistent. After all, there is nothing left to be seen. To say that this figure returns our gaze is to forget that the only gaze in question is our own. The figure acts as an intermediary, since it is nothing more than a sign, a semiotic entity constructed from our reading of a text. Yet it acts as a form of transmission and a way of circulating meaning. Its force resides in its capacity for mystery and the fact that the traces at its origin have little to do with its experience and meaning.

The aura is the recognition of uniqueness. It comes to light in the convergence of time, space, and perception, whose interactions produce an astonishing experience. To this end, Benjamin explained the aura to be a singular web of time and space, in which the close and distant, the present and absent, the almost palpable and the constantly evanescent interlink suddenly in the constitution of a complex sign. Benjamin gives an example in order to illustrate the figure's nature, which is both evanescent and immediately appealing, evidence of its inherent double distance. In this example, a man muses following "with the eye-while resting on a summer afternoon - a mountain range on the horizon or a branch that casts its shadow on the beholder is to breathe the aura of those mountains, of that branch" (Benjamin, "Work" 105). He loses himself, while becoming, in a certain way, immersed in their aura. ${ }^{13}$

It is neither the mountain nor the Vanished Child himself who possesses the aura. Moreover, the aura manifests itself under a combination of precise circumstances. The branch is not endowed with this aura. Similarly, the Vanished Child in

Jaurnal of Crass Cultural Image Studies - Revue d'Études Interculturelles de I'Image

Imaginations, I-I, 2010 Copyright @2. Open Journal Systems. ISSN - 1918-8439. 
Rembrandt's painting only becomes a figure within a singular set of conditions. It took my reading of Calle's text to make it appear.

In fact, anything can become a figure. Anything can acquire an aura. This aura does not, in itself, belong to the object. It is the result of a projection made by a subject, who attributes a value, dynamism, or even, a soul to any given object or being. It is the result of a musement, whose pure play manages to bridge all the gaps, to force associations and to actualize the creation of singular imaginary beings. Further, this transfiguration is the outcome of a process of appropriation, which does not leave the object intact, but converts it into a signifying form, an object in which the subject has emotionally and symbolically invested. If there truly was a boy who was eliminated from the painting, the figure of the Vanished Child only appears as a result of a singular reading of Sophie Calle's text. The figure draws its origins from a tragedy. Just as Benjamin's branch has no aura in itself, this figure imposes itself only after it has been integrated into the framework of a subject's life and experiences. It is by the act of reading that the absent son has become the figure of the Vanished Child.

\section{A Figural semiosis}

The figure is an auratic object. It is a complex sign, which distinguishes itself by its singularity, its value, its semiotic density, its evanescent quality, and its own logic of narration and creation of (mental or actual) images. All of these characteristics define what is meant by aura. Moreover, for Benjamin: "If we designate as aura the associations which, at home in the mémoire involontaire, tend to cluster around the object of a perception" (Baudelaire 145). The figure, as an auratic object, corresponds to this type of complex sign, which calls for the production of even more intricate images and narrations. The Vanished Child comes with his own set of images. Certain of these are tragic, while others are anecdotal. This figure is not a static and inert entity. To the contrary, it is a dynamic form, which gives rise to interpretations as well as symbolic and emotional developments, with just as large of a variety as the readers who apprehend them. However, from the very instant it is perceived, a figure imposes itself on the subject as a reality on which we can muse on our own. In this way, it also engages voluntary and involuntary memory, feelings, and affects, all of which become interlaced, giving it meaning.

It speaks of us, through Sophie Calle's text, because it is only what, without thinking, we have projected on to it. When such a figure appears, a situation opens up, through which our fears and desires are played out. It is a form that supports these feelings, while also enabling their expression. Such a figure fascinates by the intensity with which it operates. And it is intimidating because it relies essentially

Jaurnal of Crass Cultural Image Studies - Revue d'Études Interculturelles de I'Image

Imaginations, I-I, 2010 Copyright @2. Open Journal Systems. ISSN - 1918-8439. 
Imaginations / Gervais 90

on an absence. It cannot say anything by itself, but its image never stops haunting and taunting us, taking a pervasive hold on our thoughts through its very absence.

\section{References}

Auerbach, Eric. Scenes from the Drama of European Literature. Theory and history of literature, v. 9. Minneapolis: U of Minnesota P, 1984.

Barthes, Roland. A Lover's Discourse: Fragments. New York: Hill and Wang, 1978.

Benjamin, Walter. Berlin Childhood Around 1900. Cambridge: Harvard U P, 2006.

---. Charles Baudelaire: A Lyric Poet in the Era of High Capitalism. London: Verso, 1989.

---, Howard Eiland, and Michael William Jennings. "The Work of Art in the Age of Its Technological Reproducibility: Second Version." Walter Benjamin: Selected Writings. Volume 3, 1935-1938. Cambridge: Harvard U P, 2002.

---, and Rolf Tiedemann. The Arcades Project. Cambridge: Belknap Press of Harvard U P, 1999.

Calle, Sophie. Disparitions. Arles: Actes sud, 2000.

De Chirico, Giorgio. Hebdomeros: A Novel. London: Peter Owen, 1964.

DeLillo, Don. The Body Artist. New York: Scribner, 2001.

Didi-Huberman, Georges. Ce que nous voyons, ce qui nous regarde. Paris: Minuit, 1992.

Gombrowicz, Witold. Diary 3. (1961 - 1966. Evanston: Northwestern UP, 1993.

Guibert, Hervé. "Panégeryque [sic] d'une faiseuse d'histoire." Sophie Calle, à suivre. Paris: Musée d'art moderne de la Ville de Paris, 1991.

Hoopes, J., ed. “A Neglected Argument for the Reality of God.” Peirce on Signs. Chapel Hill: U of North Carolina P, 1991.

Ricoeur, Paul. Temps et récit. Paris: Seuil, 1983.

Sebeok, Thomas. The Play of Musement. Bloomington: Indiana U P, 1983.

Image Notes

Image one: Sophie Calle, Disparition, tableaux volés, Arles, Acte Sud, 2000, p. 21.

Image two: Sophie Calle, Disparition, tableaux volés, Arles, Actes Sud, 2000, p. 20.

Endnotes

1 Guillaume Bauer and Bertrand Gervais translated this article. A French version appeared in Intermédialités ( $\mathrm{nr} 7$, spring 2006). The notion of figure presented here was extensively described in 
Bertrand Gervais' essay Figures, lectures. Logiques de l'imaginaire. Tome I, Montréal, Le Quartanier, 2007, 243.

2 The French term, l'imaginaire, does not easily translate into English. Jean-Paul Sartre presented it as an act of consciousness; Jacques Lacan defined it as an order, imbedded in a triadic relationship with the Real and the Symbolic order. It is used here as an interface between the subject and the world whose actions are revealed by specific figures.

${ }^{3}$ A web version of "A Neglected Argument for the Reality of God" is available at http://en.wikisource.org/wiki/A_Neglected_Argument_for_the_Reality_of_God). The concept is a central part of my study on the labyrinth and the forms of forgetfulness in La ligne brisée: labyrinthe, oubli et violence. Logiques de l'imaginaire. Tome II, Montréal, Le Quartanier, coll. " Erres essais » 2008, 207.

${ }^{4}$ http://www.balat.fr/Le-Musement-de-Peirce-a-Lacan.html. My translation.

${ }^{5}$ http://www.balat.fr/Le-Musement-de-Peirce-a-Lacan.html. My translation.

6 Thomas Mann, Death in Venice, Bantam, 1988 (1922); Vladimir Nabokov, Lolita, Paris, Olympia Press, 1955.

7 In "Figura", Eric Auerbach reminds us that: "Originally figura, from the same stem as fingere, figulus, fictor, and effigies, meant 'plastic form" (11).

${ }^{8}$ Quotations from Sophie Calle, Disparitions are my translations.

${ }^{9}$ Sophie Calle reproduces the same textual strategy in Souvenirs de Berlin-Est (Arles, Actes sud, 1999) and Fantômes (Arles, Actes sud, 2000). Moreover, the editor brings these three books together in a boxed set with a particularly revealing title: "L'absence."

10 The painting is divided into two parts, which are almost equal in dimension. Its right side is predominately black and is occupied almost exclusively by the mother who is seated. The father and son are situated on the left side, which is less somber in color. If the father seems indifferent to the child, the two share the same space. Their physical contiguity brings them closer and assures a relationship between them.

${ }^{11}$ Quotations from Georges Didi-Huberman are my translations.

12 The Vanished Child is much like the reverend Hooper, from the Nathaniel Hawthorne short story, “The Minister's Black Veil” (The Hawthorne Treasury, New York, The Modern Library, 1999, 110-20). The minister hides his face behind a veil, which, even at the point of death, he never takes off. The mystery surrounding the reasons why he has chosen to hide his face behind this accessory is never revealed. There is no point in the story in which the pastor explains this choice, or, even, for what sin, it serves as penitence. However, this veil transforms a man who was a simple pastor into a figure holding great power. He becomes a celebrity, his sermons become widely known, and his influence grows. What the veil hides and reveals all at once, an enigma of an exaggerated sin never to be identified, gives rise to the greatest of fascinations. Like that of the Vanished Child, his aura originates from the fundamental indetermination his veil entails. 
13 Casten Strathausen effectively discerned the singular nature of this situation described by Benjamin, which is above all else an experience. Strathausen emphasizes the way in which the aura is an ephemeral specter, which is captured in the web of time and space. As he writes, "It does not refer to an independent, material thing, but describes a particular form of human experience. " (Carsten Strathausen, "Benjamin's Aura and the Broken Heart of Modernity," in Benjamin's Blind Spot, Lise Patt, ed., New York: Institute of Cultural Inquiry, 2001, 5). 